\title{
Efektivitas model konseling aktualisasi diri untuk mengembangkan kecakapan pribadi
}

\author{
Mamat Supriatna \\ Bimbingan dan Konseling, Universitas Pendidikan Indonesia \\ Email: ma2t.supri@upi.edu
}

(Diterima: 01-April-2017; di revisi: 09-Mei-2017; dipublikasikan: 23-Juni-2017)

\begin{abstract}
This research is aimed to produce an effective self-actualization counseling model to develop personal skills. The counseling model was developed based on a humanistic approach and combined with preliminary study results on the personal skills profile of Indonesian Education University (UPI) students in 2009/2010. The method used is research and development (research and depelovment) which consists of four main steps, namely preliminary study, model development, model rational validation, and empirical validation model. The results showed that in general the attainment of personal skills of research subjects has not been optimal, both in terms of understanding himself, understand others, or in social interaction meaningfully. Based on rational and empirical validation tests, it was found that self-actualization counseling models are effective for developing personal skills, covering almost all indicators in each dimension of the skill.
\end{abstract}

Keywords: Humanistic; Personal Skills; Self-Actualization Counseling; Services

\begin{abstract}
Abstrak: Penelitian ini ditujukan untuk menghasilkan model konseling aktualisasi diri yang efektif untuk mengembangkan kecakapan pribadi. Model konseling tersebut dikembangkan berdasarkan pendekatan humanistik dan dipadukan dengan hasil studi pendahuluan tentang profil kecakapan pribadi mahasiswa Universitas Pendidikan Indonesia (UPI) tahun 2009/2010. Metode yang digunakan adalah penelitian dan pengembangan (research and depelovment) yang terdiri atas empat langkah utama, yaitu studi pendahuluan, pengembangan model, validasi rasional model, dan validasi empirik model. Hasil penelitian menunjukkan bahwa pada umumnya pencapaian kecakapan pribadi subjek penelitian belum optimal, baik dalam aspek memahami dirinya sendiri, memahami orang lain, maupun dalam berinteraksi sosial secara bermakna. Berdasarkan uji validasi rasional dan empirik, ditemukan bahwa model konseling aktualisasi diri efektif untuk mengembangkan kecakapan pribadi, yang melingkupi hampir semua indikator pada setiap dimensi kecakapan tersebut.
\end{abstract}

Kata Kunci : Humanistik; Kecakapan Pribadi; Konseling Aktualisasi Diri; Layanan.

Copyright $(2017$ Universitas Negeri Makassar.. This is an open access article under the CC BYNC-ND license (http://creativecommons.org/licenses/by-nc-nd/4.0/).

\section{PENDAHULUAN}

Selama dekade 1960-an - 1990-an, gerakan pengembangan kecakapan hidup melalui konseling dalam adegan (setting) pendidikan tinggi dapat dipandang sebagai tanggapan terhadap kebutuhan individu (mahasiswa) agar mencapai tugas-tugas perkembangan dasar yang terlingkup dalam proses pengembangan sumberdaya manusia. Dalam hasil penelitian 
Picklesimer dan Miller (1998), terungkapkan empat gerakan pemikiran dan praktik psikologis sebagai upaya pengembangan kecakapan hidup, yang termasuk pengembangan kecakapan pribadi. Gerakan ke-1 terapi dan konseling kelompok; dan ke-2 teori perkembangan manusia yang dipelopori oleh Erikson, Super, dan Havighurst; kemudian gerakan ke-3 didasarkan atas karya Carkhuff's tentang pengembangan sumberdaya manusia. Gerakan ke-4 dipelopori oleh Brook's dalam bentuk pengembangan model latihan kecakapan hidup (life skills training model). Melalui studi Delphi, ia mengidentifikasi empat kategori pengembangan kecakapan hidup, yaitu kecakapan: (1) relasi manusiawi dan komunikasi interpersonal; (2) pemecahan-masalah dan pengambilankeputusan; (3) pemeliharaan kesehatan dan kebugaran fisik; dan (4) identifikasi perkembangan dan tujuan hidup, baik yang dipraktikkan di lingkungan keluarga, masyarakat, pekerjaan, maupun sekolah.

Menurut Gazda dan koleganya (Picklesimer dan Miller, 1998), taksonomi kecakapan hidup yang dihasilkan studi tersebut di samping merupakan kompromi dalam menafsirkan teori perkembangan manusia, tetapi juga merupakan upaya komprehensif pertama untuk menciptakan model pengembangan kecakapan hidup dengan menggunakan dasar pemikiran perkembangan.

Meskipun teori perkembangan menyediakan kerangka kerja bagi pengembangan mahasiswa secara utuh, tetapi lembaga pendidikan tinggi sebagaimana pendidikan formal lainnya telah memfokuskan pada belajar untuk menguasai kecakapan mental atau intelektual, alih-alih kecakapan pribadi dan sosial. Kondisi tersebut dapat dimaknai bahwa terbuka peluang bagi pengembangan dan pengimplementasian berbagai strategi pengembangan kecakapan pribadi dan sosial mahasiswa, baik yang terintegrasi dalam perkuliahan maupun program yang dirancang sebagai sistem layanan pendukung, dalam hal ini bimbingan dan konseling.

Para ahli dalam bidang psikologi dan konseling telah lama tertarik untuk mengkaji dan mengembangkan kecakapan pribadi manusia. Berdasarkan catatan Kumpfer (2010), peningkatan yang dimaksud terutama dalam bentuk penelitian terapan tentang Program Pelatihan Kecakapan Hidup (Life Skill Training Program) yang berbasis teori belajar sosial dari Bandura dan teori masalah-perilaku dari Jessor dan Jessor. Penelitian-penelitian yang dimaksud ditujukan untuk mengembangkan kecakapan pribadi dan sosial para subjek yang menderita ketergantungan kepada alkohol dan narkoba (narkotika, psikotrofika, dan bahan adiktif lainnya). Adapun strategi intervensi yang dipergunakan para peneliti umumnya meliputi tiga pendekatan, yaitu: (1) pelatihan kecakapan resistensi sosial, yang diselenggarakan selama 3 - 12 sesi; (2) penyuntikan psikologis (psychological inoculation), melalui suatu analisis atas beragam bentuk reklame; dan (3) pendidikan normatif.

Pada penghujung Abad XX penelitian tentang fungsi-fungsi otak semakin pesat dan berpengaruh positif terhadap perkembangan teori kecerdasan. Tercatat dalam perkembangan ilmiah, Gardner antara tahun 1983 - 2003 mengembangkan kecerdasan jamak; Sternberg antara 1985 - 1996, mengembangkan kecerdasan praktikal sebagai kemampuan penerapan pengetahuan dalam kehidupan sehari-hari (Wu, 1998; 2001; 2003). Paul G. Stoltz (1997), menerbitkan kecerdasan adversitas (ketabahan). Daniel Goleman melalui karyanya telah mempopulerkan kecerdasan emosional (emotional intelligence, 1997). Kemudian pada saat memasuki Abad XXI, Zohar \& Marshall (2000), menerbitkan kecerdasan spiritual, yang mengungkapkan penandaan-penandaan pemecahan masalah makna dan nilai. Goleman kembali memperluas wawasan tentang kecerdasan sosial (social intelligence, 2007), dan kecerdasan ekologis (ecological intelligence, 2009).

Perkembangan tersebut berimplikasi dinamis bagi penelitian tentang sumberdaya manusia yang terfokus pada dimensi personal, sosial, dan spiritual di samping intelektual; pengembangan berbagai strategi pendidikan, serta model bimbingan dan konseling dalam upaya terpadu memfasilitasi seluruh dimensi kehidupan manusia.

Dalam tulisan ini, pengembangan kecakapan pribadi sebagai bagian dari kecakapan hidup dipandang sebagai proses pendidikan sepanjang rentang kehidupan individu. Pengembangan kecakapan pribadi melalui konseling dianggap sebagai salah satu upaya pendidikan yang memfasilitasi individu dalam mengaktualisasikan dirinya, sehingga menjadi pribadi yang berkembang secara penuh (full person), atau sesuai dengan potensinya. Dengan kata lain, pribadi yang berkembang adalah 


\section{3 | Jurnal Psikologi Pendidikan \& Konseling Vol. 3 No.1 Juni 2017}

seorang pribadi yang berusaha untuk mengaktualisasikan fitrahnya sebagai manusia.

Model konseling aktualisasi diri merupakan layanan konseling yang dirancang sebagai bagian integral dari keseluruhan program pendidikan, dan terfokuskan pada kebutuhan, kekuatan, minat, dan isu-isu yang berkaitan dengan tahapan perkembangan individu. Konseling aktualisasi diri dimaksudkan sebagai upaya pengembangan kecakapan pribadi mahasiswa, baik yang meliputi dimensi kecakapan intrapersonal, interpersonal, maupun interaktif. Dalam definisi tersebut terkandung makna hubungan bantuan (helping relationship) antara konselor dengan konseli, sebagai upaya fasilitasi agar konseli berkembang kecakapan pribadinya secara optimal atau mencapai aktualisasi diri.

Abraham Maslow (Supriatna, 2016b) mengungkapkan delapan batasan perilaku dan prosedur aktual tentang aktualisasi diri, yaitu: (1) mengalami sepenuhnya, jelas, tanpa pamrih, dengan penuh konsentrasi dan penyerapan total; (2) proses yang berkelanjutan, yang berarti setiap orang membuat pilihan dan masing-masing pilihan sebagai pilihan pertumbuhan dalam hidupnya. Saat seseorang menentukan pilihan, pada dasarnya ia menuju aktualisasi diri. Hal ini didasarkan atas premis bahwa hidup sebagai proses pilihan, baik untuk maju maupun mundur. Pada satu sisi, orang mungkin bergerak ke arah pilihan untuk bertahan atau menuju keselamatan, tetapi di sisi lain ada pilihan untuk pertumbuhan; (3) ada diri yang harus diaktualisasikan. Seorang manusia bukanlah tabula rasa, bukan kertas kosong atau segumpal tanah liat yang pasif. Dia adalah sesuatu yang sudah ada dan memiliki kesiapan berinteraksi yang khas. Dengan adanya diri, berarti membiarkan diri hadir atau aktif secara intensional; (4) mengambil tanggung jawab. Seseorang yang mengambil tanggung jawab berarti melangkah besar terhadap aktualisasi. Dengan kata lain, setiap kali seseorang mengambil tanggung jawab, ini merupakan aktualisasi diri; (5) berani untuk mengungkapkan selera sendiri, mencoba sesuatu dengan cara sendiri, dan atau mengungkapkan kesukaan yang mungkin berbeda dari orang lain; (6) bukan hanya tujuan akhir yang akan dicapai, tetapi juga sebagai proses aktualisasi potensi seseorang setiap saat, dalam jumlah dan bentuk apapun. Aktualisasi diri berarti bekerja dengan baik atau melakukan hal terbaik yang seseorang ingin lakukan; (7) pencapaian pengalaman puncak sebagai saat-saat yang tidak kekal (transient). Saat-saat seperti itu tidak bisa dibeli, tidak dapat dijamin, bahkan tidak dapat dicari. Akan tetapi seseorang dapat mengatur kondisi agar pengalaman puncak lebih mungkin dicapai, atau dapat mengatur suatu kondisi sehingga terhindar dari yang kurang diinginkan. Pengalaman puncak itu dapat diumpamakan seperti orang yang "terkejut dengan sukacita", karena sesuatu yang direncanakan atau dicitacitakan terlaksana; dan (8) membuka diri sendiri, baik yang berhubungan dengan kelebihan maupun kekurangan dari diri. Ini berarti pula mengungkapkan sesuatu yang ada pada diri, baik yang menyenangkan maupun yang menyakitkan hingga diketahui orang lain.

Dalam penelitian ini, model konseling aktualisasi diri didefinisikan secara operasional sebagai layanan fasilitasi dari konselor (peneliti) kepada konseli (mahasiswa subjek studi) melalui proses hubungan bantuan berkesinambungan, yang berisi tahapan aktivitas: (1) Pengungkapan Awal; (2) Refleksi Kondisi Diri; (3) Mengungkap Sifat-sifat Diri; (4) Telaah Wajah; (5) Menghayati Keberanian Diri Orang Lain; (6) Menghargai Pengalaman yang Paling Berkesan; (7) Berperan Mengatasi Konflik; dan (8) Refleksi Akhir. Secara visual, pengembangan kecakapan pribadi mahasiswa melalui model konseling aktualisasi diri tertera pada gambar 1. sebagai berikut. 


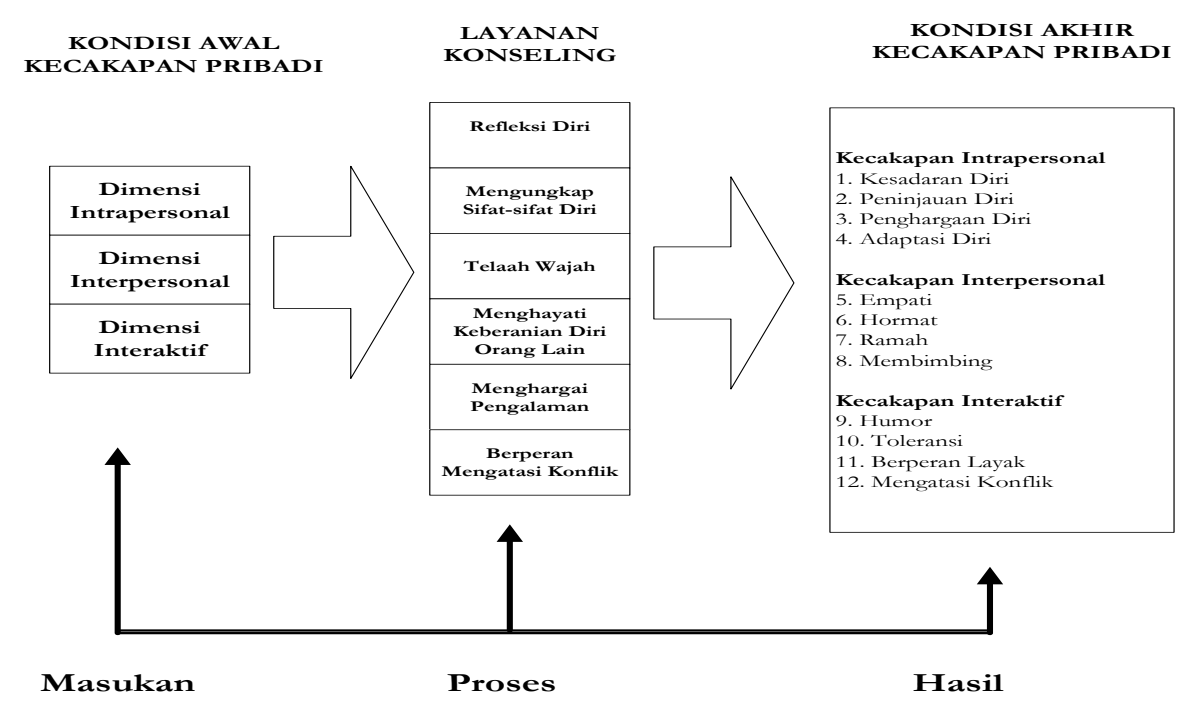

Gambar 1. Pengembangan Kecakapan Pribadi Mahasiswa Melalui Model Konseling Aktualisasi Diri

\section{METODE}

Dalam penelitian ini digunakan pendekatan kuantitatif dan kualitatif. Pendekatan kuantitatif dipergunakan terutama dalam pemaparan deskripsi profil kecakapan pribadi mahasiswa; sedangkan pendekatan kualitatif digunakan lebih intensif pada saat analisis profil dan hasil perlakuan terhadap subjek penelitian. Bryman (Brannen, 1997:37), mengungkapkan ada tiga pendekatan pokok, yaitu: (1) pendekatan kualitatif sebagai penunjang penelitian kuantitatif, (2) pendekatan kuantitatif sebagai penunjang penelitian kualitatif, dan (3) kedua pendekatan yang setara. Dalam penelitian ini digunakan pendekatan pertama, yaitu data kualitatif sebagai penunjang data kuantitatif.

Prosedur penelitian dan pengembangan (research and development) dipergunakan, berdasarkan alasan bahwa penelitian ini dimaksudkan untuk menghasilkan produk pendidikan, yaitu model konseling aktualisasi diri untuk mengembangkan kecakapan pribadi mahasiswa. Secara konseptual, prosedur tersebut dikemukakan oleh Borg dan Gall (2003) meliputi sembilan langkah, yaitu: (1) studi pendahuluan, (2) perencanaan, (3) pengembangan model awal, (4) revisi model awal, (5) ujicoba terbatas, (6) revisi model hasil ujicoba, (7) ujicoba lebih luas, (8) finalisasi model, (9) diseminasi dan implementasi model.

Penelitian ini terbatas sampai tahap enam (6), yang terbagi menjadi empat langkah utama (studi pendahuluan, pengembangan model, validasi model hipotetik, dan ujicoba terbatas) dengan subjek penelitian yang beragam. Pada langkah studi pendahuluan, subjek adalah mahasiswa UPI yang berasal dari tujuh fakultas berjumlah 409 mahasiswa, yang ditentukan secara non-random melalui teknik purposive sampling (Fraenkel \& Wallen, 1993).

Pada langkah pengembangan dan validasi model hipotetik, subjek yang dilibatkan meliputi pakar bimbingan dan konseling. Pada langkah uji-coba model, subjek penelitian adalah mahasiswa jurusan Pendidikan Bahasa Indonesia (PBI) dan Psikologi Pendidikan dan Bimbingan (PPB) yang ditentukan secara purposive. Pada masing-masing jurusan tersebut dibentuk kelompok eksperimen (dari kelas A) dan kelompok kontrol (dari kelas B). Mahasiswa dari jurusan PBI dianggap mewakili mereka yang diproyeksikan menjadi tenaga pendidik atau guru mata pelajaran; sedangkan mahasiswa jurusan PPB diproyeksikan menjadi pendidik non guru mata pelajaran. Kedua kelompok subjek studi menyepakati untuk mengikuti setiap tahapan layanan konseling.

Penentuan kelompok untuk uji-coba model didasarkan atas pertimbangan, bahwa: (1) aktivitas kelompok ditawarkan sebagai layanan dalam adegan rentang kehidupan individu, yang disebut aktivitas kelompok bimbingan/pendidikan-psikologis

(guidance/psychoeducational group); (2) kelompok-kelompok tersebut dibentuk dalam rangka pengembangan kecakapan pribadi yang termasuk ke dalam rumpun kecakapan hidup, yang terutama diperuntukkan bagi mereka yang mengalami defisit perilaku; dan (3) jenis 


\section{5 | Jurnal Psikologi Pendidikan \& Konseling Vol. 3 No.1 Juni 2017}

kelompok menekankan pada "bagaimana" pendekatan/metode/teknik layanan yang sesuai memungkinkan untuk dipergunakan, termasuk penggunaan film, drama, demonstrasi, bermain peran, dan mengundang pembicara tamu; dan (4) ukuran kelompok pengembangan kecakapan pribadi disesuaikan dengan adegan layanan yang biasanya berjumlah berkisar 10-40 individu. Dalam hal ini, pemimpin kelompok (konselor) bertanggung jawab untuk mengelola kelompok, menyebarluaskan informasi, dan biasanya dianggap kompeten di bidang yang sedang dibahas. Kelompok bimbingan/pendidikanpsikologis dirancang secara umum untuk memenuhi kebutuhan agar orang berfungsi dengan baik (Gladding, 1995).

\section{HASIL DAN PEMBAHASAN}

Dalam rangka menghasilkan model konseling yang teruji secara efektif, maka langkah awal adalah pengujian kelayakan model secara rasional. Uji kelayakan model untuk validasi rasional dilakukan melalui penilaian pakar (expert judgment). Pakar yang terlibat dalam penilaian model berjumlah lima orang yang memiliki latar belakang pendidikan Magister (S-2) dan Doktor (S-3) dalam bidang Bimbingan dan Konseling.

Hasil validasi pakar terhadap dimensi isi menunjukkan bahwa secara keseluruhan model sudah memadai sehingga memenuhi syarat kelayakan teoretis. Walaupun demikian, pakar menyarankan untuk lebih menegaskan penggunaan teknik yang dalam setiap sesi serta mengendalikan kemungkinan adanya pengaruh dari faktor yang tidak diduga.

Uji coba model konseling aktualisasi diri dilakukan melibatkan subjek penelitian, hingga diperoleh data yang dianalisis dengan mempergunakan teknik anakova. Sebelum data hasil layanan (perlakuan) diolah lebih lanjut, terlebih dahulu dilakukan uji normalitas dengan statistik uji Z Kolmogrov-Smirnov ( $p>0,05)$ dan uji homogenitas varians $(p>0,05)$. Hasil uji normalitas dan homogenitas varians menunjukkan bahwa data tersebut memiliki distribusi normal dan varians yang homogen. Hipotesis penelitian berbunyi: "Model Konseling Aktualisasi Diri efektif untuk mengembangkan Kecakapan Pribadi Mahasiswa dibandingkan dengan model lain (Kontrol)". Adapun hipotesis statistiknya adalah sebagai berikut:

$$
\begin{aligned}
& \mathrm{H}_{0}: \mu_{\text {eksperimen }}=\mu_{\text {kontrol }} \\
& \mathrm{H}_{1}: \mu_{\text {eksperimen }}>\mu_{\text {kontrol }}
\end{aligned}
$$

Hasil analisis kovarian yang ditunjang oleh hasil deskripsi data dari kelompok eksperimen dan kontrol pada pra tes dan pasca tes tertuang pada Tabel 6.4 dan Tabel 7.4

\begin{tabular}{|c|c|c|c|c|c|c|}
\hline Jurusan & Sumber Variasi & $\begin{array}{c}\text { Jumlah } \\
\text { Kuadrat }\end{array}$ & df & $\begin{array}{c}\text { Rata-rata } \\
\text { Kuadrat }\end{array}$ & $\mathbf{F}$ & Sig \\
\hline \multirow{4}{*}{ Keseluruhan } & Kelompok & 6461,374 & 1 & 6461,374 & 8,727 & 0,005 \\
\hline & Kovariat & 5800,736 & 1 & 5800,736 & 7,834 & 0,007 \\
\hline & Galat & 42203,831 & 57 & 740,418 & & \\
\hline & Total Dikoreksi & 53212,583 & 59 & & & \\
\hline \multirow{4}{*}{ PPB } & Kelompok & 3753,207 & 1 & 3753,207 & 6,884 & 0,014 \\
\hline & Kovariat & 8538,775 & 1 & 8538,775 & 15,661 & 0,000 \\
\hline & Galat & 14720,958 & 27 & 545,221 & & \\
\hline & Total Dikoreksi & 25069,367 & 29 & & & \\
\hline \multirow{4}{*}{$\begin{array}{l}\text { Pendidikan } \\
\text { Bahasa } \\
\text { Indonesia }\end{array}$} & Kelompok & 3554,901 & 1 & 3554,901 & 4,416 & 0,045 \\
\hline & Kovariat & 445,674 & 1 & 445,674 & 0,554 & 0,463 \\
\hline & Galat & 21735,66 & 27 & 805,024 & & \\
\hline & Total Dikoreksi & 25723,867 & 29 & & & \\
\hline
\end{tabular}

Tabel 6.4. Hasil Analisis Kovarian Kelompok Eksperimen dan Kontrol

*) Keseluruhan dimaksudkan sebagai data gabungan dari subjek penelitian PPB dan PBI 
Tabel 7.4 Deskripsi Data Pra-Pasca Tes Kelompok Eksperimen dan Kontrol

\begin{tabular}{|c|c|c|c|c|}
\hline Jurusan & \multicolumn{2}{|c|}{ Kelompok } & Rata-rata & $\begin{array}{c}\text { Standar } \\
\text { Deviasi }\end{array}$ \\
\hline \multirow{4}{*}{ Keseluruhan } & \multirow{2}{*}{ Eksperimen } & Pra Tes & 181,13 & 20,91 \\
\hline & & Pasca Tes & 206,40 & 25,94 \\
\hline & \multirow{2}{*}{ Kontrol } & Pra Tes & 187,10 & 30,98 \\
\hline & & Pasca Tes & 187,77 & 31,35 \\
\hline \multirow{4}{*}{ PPB } & \multirow{2}{*}{ Eksperimen } & Pra Tes & 186,73 & 23,23 \\
\hline & & Pasca Tes & 211,20 & 30,63 \\
\hline & \multirow{2}{*}{ Kontrol } & Pra Tes & 198,87 & 33,41 \\
\hline & & Pasca Tes & 195,67 & 26,89 \\
\hline \multirow{4}{*}{$\begin{array}{l}\text { Pendidikan } \\
\text { Bahasa Indonesia }\end{array}$} & \multirow{2}{*}{ Eksperimen } & Pra Tes & 175,53 & 17,29 \\
\hline & & Pasca Tes & 201,60 & 20,14 \\
\hline & \multirow{2}{*}{ Kontrol } & Pra Tes & 175,33 & 23,98 \\
\hline & & Pasca Tes & 179,87 & 34,33 \\
\hline
\end{tabular}

*) Keseluruhan dimaksudkan sebagai data gabungan dari subjek penelitian jurusan PPB dan PBI

Tabel 6.4 dan 7.4 di atas menunjukkan bahwa baik secara keseluruhan maupun setiap jurusan diperoleh hasil analisis: (1) efek utama (kelompok), yaitu uji efektivitas model konseling aktualisasi diri dibandingkan dengan "model lain"; dan (2) kovariat, yaitu hubungan linearitas antara kecakapan pribadi mahasiswa sebelum dan sesudah layanan (perlakuan).

1) Efek Utama

Berdasarkan Tabel 6.4 diperoleh gambaran bahwa secara keseluruhan efek utama (kelompok) menunjukkan hasil yang signifikan (nilai signifikansi di bawah 0,05 atau $\mathrm{p}<0,05$ ). Hal ini berarti bahwa terdapat perbedaan yang signifikan antara kecakapan pribadi mahasiswa kelompok eksperimen dan kelompok kontrol setelah perlakuan dengan mengendalikan kecakapan pribadi sebelum perlakuan.

Pada Tabel 7.4 terlihat bahwa rata-rata skor kecakapan pribadi pasca tes (setelah perlakuan) pada kelompok eksperimen (ratarata $=206,40$, standar deviasi $=25,94$ ) lebih tinggi dibandingkan kelompok kontrol (rata-rata $=187,77$, standar deviasi =30,98). Hasil ini menunjukkan bahwa kelompok eksperimen mengalami perubahan kecakapan pribadi yang signifikan dari kondisi sebelum hingga sesudah perlakuan.

Apabila efek utama dilihat setiap jurusan (Jurusan PPB dan PBI) hasilnya sebagai berikut. Pada jurusan PPB efek utama (kelompok) menunjukkan hasil yang signifikan yang dapat dilihat dari nilai signifikansi yang di bawah 0,05 $(p<0,05)$. Hal ini berarti bahwa ada perbedaan kecakapan pribadi yang signifikan setelah perlakuan antara kelompok eksperimen dan kelompok kontrol dengan mengendalikan kecakapan pribadi sebelum perlakuan. Dilihat dari Tabel 7.4 tampak bahwa rata-rata skor kecakapan pribadi setelah perlakuan pada kelompok eksperimen (rata-rata $=211,20$, standar deviasi $=30,63$ ) lebih tinggi dibandingkan kelompok kontrol (rata-rata $=195,67$, standar deviasi $=26,89$ ). Hasil ini menunjukkan bahwa kelompok eksperimen mengalami perubahan kecakapan pribadi yang signifikan dari kondisi sebelum hingga setelah perlakuan.

Selanjutnya pada jurusan PBI efek utama (kelompok) menunjukkan hasil yang signifikan yang dapat dilihat dari nilai signifikansi yang di bawah $0,05(\mathrm{p}<0,05)$. Hal ini berarti bahwa ada perbedaan kecakapan pribadi yang signifikan setelah perlakuan antara kelompok eksperimen dan kelompok kontrol dengan mengendalikan kecakapan pribadi sebelum perlakuan. Dilihat dari Tabel 7.4 tampak bahwa rata-rata skor kecakapan pribadi setelah perlakuan pada kelompok eksperimen (rata-rata $=201,60$, standar deviasi $=20,14)$ lebih tinggi dibandingkan kelompok kontrol (rata-rata $=179,87$, standar deviasi $=34,33$ ). Hasil ini menunjukkan bahwa kelompok eksperimen mengalami perubahan kecakapan pribadi yang signifikan dari kondisi sebelum perlakuan hingga setelah perlakuan.

2) Kovariat

Dalam hal ini, kovariat menunjukkan seberapa jauh hubungan antara kecakapan pribadi mahasiswa sebelum dan sesudah 


\section{7 | Jurnal Psikologi Pendidikan \& Konseling Vol. 3 No.1 Juni 2017}

perlakuan (linearitas antara skor kecakapan pribadi pra dan pasca perlakuan). Nilai kovariat yang signifikan menunjukkan bahwa kovariat (kecakapan pribadi sebelum perlakuan) dan variabel dependen (kecakapan pribadi setelah perlakuan) membentuk hubungan linier.

Dengan menggunakan bahasa analisis regresi, hasil tersebut menunjukkan bahwa skor pra (kecakapan pribadi sebelum perlakuan) dapat memprediksi skor pasca (kecakapan pribadi setelah perlakuan). Semakin besar skor pra, maka semakin besar pula skor pasca. Hasil ini mengandung beberapa temuan dan implikasi sebagai berikut. Pertama, upaya pengendalian secara statistik terhadap skor kecakapan pribadi sebelum perlakuan (pra tes) dapat dilakukan. Dengan kata lain, analisis kovarian yang dilakukan bermanfaat, kecuali pada jurusan PBI menunjukkan nilai yang tidak signifikan ( $p>0,05)$. Hal ini berarti bahwa kontrol secara statistik tidak dapat dilakukan karena variabel pra tes tidak memiliki peranan. Kedua, kovariat yang menghasilkan nilai yang signifikan menunjukkan bahwa perlakuan yang diberikan kepada subjek memberikan efek yang berbedabeda. Perlakuan memberikan efek yang besar pada kelompok eksperimen, akan tetapi tidak seberapa besar pada kelompok kontrol.

Berdasarkan uraian di atas dapat disimpulkan bahwa model konseling aktualisasi diri efektif untuk mengembangkan kecakapan pribadi mahasiswa baik secara keseluruhan maupun berdasarkan jurusan. Dari 12 indikator kecakapan pribadi, ada sembilan indikator yang signifikan (kesadaran diri, peninjauan diri, adaptasi diri, empati, hormat, ramah, membimbing, berperan layak, dan mengatasi konflik), dan tiga indikator yang tidak signifikan (penghargaan diri, humor, toleransi). Bagi indikator yang signifikan berarti bahwa terdapat perbedaan yang signifikan antara kecakapan pribadi mahasiswa kelompok eksperimen dan kelompok kontrol setelah perlakuan. Fakta empirik menunjukkan bahwa rata-rata skor indikator kecakapan pribadi setelah perlakuan pada kelompok eksperimen selalu lebih tinggi dibandingkan dengan rata-rata kelompok kontrol. Hal ini berarti bahwa pada indikator-indikator kecakapan pribadi, kelompok eksperimen mengalami perubahan yang signifikan dari kondisi sebelum hingga sesudah perlakuan.

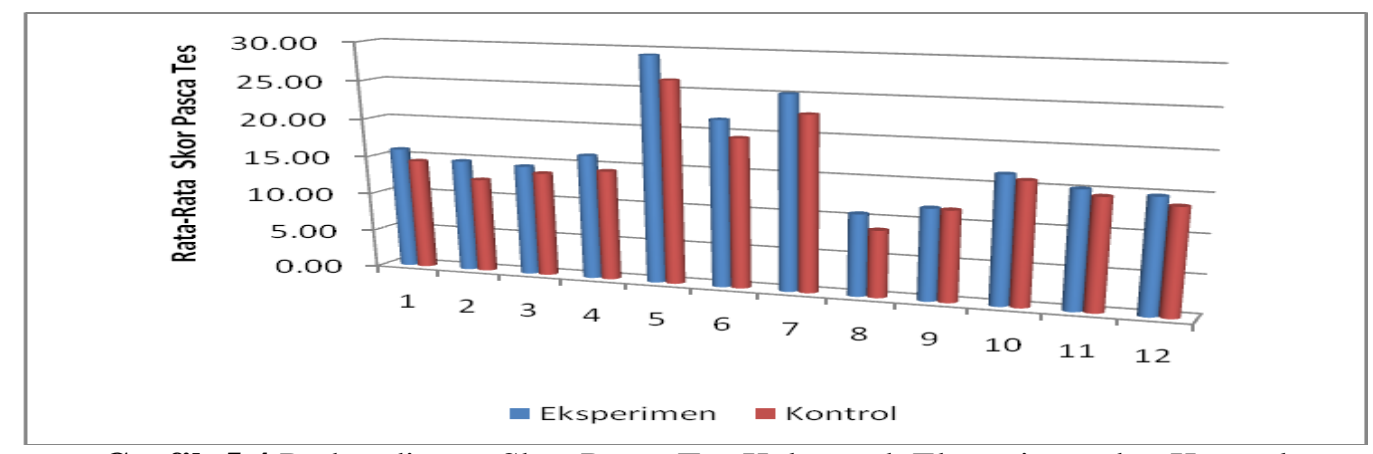

Grafik 5.4 Perbandingan Skor Pasca Tes Kelompok Eksperimen dan Kontrol

Ujicoba terbatas model konseling aktualisasi diri menunjukkan hasil yang sangat memuaskan, sekaligus mengindikasikan efektivitasnya untuk membantu pengembangan kecakapan pribadi mahasiswa. Hasil ujicoba model menunjukkan bahwa hampir semua indikator kecakapan pribadi mahasiswa dapat berkembang secara signifikan setelah diselenggarakan layanan model konseling aktualisasi diri.

Di samping itu, perlu dikemukakan bahwa "Model Konseling Aktualisasi Diri" telah diadaptasi dan diujicobakan oleh Aam Imaddudin (2011) pada jenjang pendidikan dasar di Kabupaten Bandung. Hasil penelitiannya menunjukkan bahwa model tersebut efektif untuk mengembangkan kecerdasan spiritual siswa sekolah dasar

Makna yang tersirat dari temuan-temuan tersebut adalah bahwa belajar bagi mahasiswa atau perkuliahan pada institusi pendidikan tinggi mesti diperluas daya rambahnya. Belajar pada institusi pendidikan tinggi memiliki karakteristik yang berbeda dari belajar pada institusi pendidikan sebelumnya. Karakteristik utama belajar pada tingkat ini adalah kemandirian, baik dalam pelaksanaan kegiatan akademik maupun non-akademik. Dalam kegiatan akademik, mahasiswa dipandang telah cukup mampu untuk memilih dan menentukan program studi yang sesuai dengan bakat, minat dan cita-citanya. Mahasiswa juga dituntut untuk lebih banyak 
belajar mandiri, mencari dan menemukan sumber-sumber belajar dan referensi sendiri, serta mengkaji dan memperdalam bahan perkuliahan tanpa banyak diatur, diawasi dan dikendalikan oleh dosen-dosennya. Di samping itu, dalam kegiatan non-akademik mahasiswa telah dipandang cukup mampu, baik dalam memahami dirinya, memahami orang lain, maupun berinteraksi dalam lingkungan sosial secara bermakna.

Kondisi demikian sejalan dengan perkembangan mahasiswa yang memasuki fase dewasa muda. Indikasi perilaku yang tampak selama fase tersebut (usia $18-21$ tahun) menurut Gerald L. Stone (1995), yaitu: (a) terbentuknya relasi jangka panjang yang disertai komitmen, (b) terjadinya proses individuasi dan perkembangan identitas, (c) proses definisi diri dalam kaitannya dengan penghayatan pengalaman masa lalu, masa kini dan harapan masa depan, (d) adanya tantangan pendidikan atau karier dan pengambilan keputusan tentang format kehidupan, dan (e) adanya tantangan akan ketidakpastian masa depan.

Belajar pada jenjang pendidikan tinggi bukan sekadar datang ke kampus, menghadiri kelas, ikut serta dalam ujian, kemudian lulus. Aktivitas belajar mahasiswa tidak sebatas di ruang kelas, melainkan juga berhubungan dengan manusia, baik mahasiswa yang lain, lingkungan sosial di masyarakat, maupun menjalani kehidupan yang berbeda dari rutinitas pendidikan pada jenjang sebelumnya. Dalam arti yang luas (Sinamo, 2001), belajar adalah aktivitas untuk meningkatkan pengertian atau kesadaran tentang diri sendiri (self-awareness), dunia sekitar (cosmo-awareness), termasuk kesadaran tentang Tuhan dan dunia gaib (theoawareness) serta relasi ketiganya (relationship-awareness) ke tingkat yang lebih dalam dan tinggi. Belajar seperti itu dalam rangka mencapai substansi kecakapan hidup (Coppens, 2006), atau menjadi pribadi yang tegar (Sukartini, 2003). Pribadi yang demikian dapat tergambarkan pada mereka yang hidup berkarakter atau dilandasi nilai-nilai kemanusiaan, dan setia mengabdi demi kemajuan bangsa dan negara.

Menurut Aryan Pardiansyah (2003), orang yang berkarakter adalah orang yang senantiasa digerakkan oleh nilai-nilai (valuedriven) kemanusiaan, seperti integritas, kerendahan hati, kesetiaan, pengendalian diri, keberanian, kesabaran, kerajinan, kesederhanaan, dan sebagainya. Berbeda dengan orang yang tidak berkarakter, yaitu yang hidupnya dikendalikan oleh kepentingan sendiri (interestdriven). Orang yang berkarakter tidak melakukan korupsi bukan karena takut akan risikonya, tapi semata-mata karena tidak ingin mengambil sesuatu yang bukan haknya.

Hay, Castle, dan Jewett (1994), mengungkapkan bahwa dalam kehidupan seseorang yang berkarakter tumbuh-kembang dimensi: (1) kepekaan sosial; (2) melindungi dan menjaga hubungan baik dengan orang lain; (3) selalu mengembangkan sifat berbagi, bekerja sama, dan adil; (4) pribadi yang suka menolong dan membantu orang lain; (5) pribadi yang jujur; (6) selalu mengedepankan moral dan etika; (7) selalu mengontrol dan introspeksi diri; dan (8) mampu menyelesaikan masalah dan konflik sosial.

\section{SIMPULAN DAN SARAN}

Hasil validasi rasional pakar bimbingan dan konseling terhadap model tersebut menunjukkan kelayakan model atau layanan fasilitasi untuk mengembangkan kecakapan pribadi mahasiswa. Hasil uji coba menunjukkan bahwa model konseling aktualisasi diri merupakan layanan fasilitasi yang bersifat preventif-pengembangan, yang ternyata efektif untuk mengembangkan kecakapan pribadi mahasiswa, baik yang meliputi dimensi kecakapan intrapersonal, interpersonal, maupun interaktif.

Oleh karena itu, unit-unit Layanan Bimbingan dan Konseling yang ada di lembaga pendidikan tinggi dapat mengimplementasikan model konseling aktualisasi diri dalam adegan bimbingan, pembelajaran, pengembangan kecakapan hidup atau pengembangan karakter. Bila model konseling aktualisasi diri diimplementasikan dalam rangka pengembangan kapasitas Guru Bimbingan dan Konseling atau Konselor, maka layaknya model dilengkapi dengan panduan praktikum dengan strategi yang bersifat dialogis, reflektif, dan ekspresif.

Model konseling aktualisasi diri terbukti efektif untuk mengembangkan hampir semua indikator kecakapan pribadi mahasiswa; kecuali pada indikator kecakapan pribadi mahasiswa yang berkembang tidak signifikan, yaitu pada indikator penghargaan diri (dimensi kecakapan intrapersonal), humor dan toleransi (dimensi kecakapan interaktif). Dengan demikian, implikasi dari temuan-temuan penelitian ini dapat memperluas ranah kebijakan strategis pendidikan, antara lain: (1) dalam membangun 


\section{9 | Jurnal Psikologi Pendidikan \& Konseling Vol. 3 No.1 Juni 2017}

budaya dan karakter bangsa yang menjadi fokus pendidikan sekarang dan ke depan, seyogyanya menyertakan rujukan nilai-nilai kemanusiaan berdasarkan hasil penelitian dari negeri sendiri dan dipandang berlaku universal; (2) pembinaan peserta didik (mahasiswa) sebagai elit pemuda hendaknya mengintegrasikan berbagai aspek, baik fisikal, intelektual, personal, sosial, maupun spiritual.

\section{DAFTAR RUJUKAN}

Borg, W.R. \& Gall, M.D. (2003). Educational Research; An Introduction. London: Longman, Inc.

Brannen, J. (Ed). (1995). Mixing Methods: qualitative and quantitative research. Sydney: Avebury.

Coppens, S. (2006). Re-Introducing Life-Skills Education and Value Clarification in the Learning Environment. Colloque international, Education, Violences, Conflits et Perspectives de Paix en Afrique.

Fraenkel, J.R \& Wallen, N.E. (1993). How to Design and Evaluate Research in Education. New York: McGraw-Hill Inc.

Gardner, H. (2003). Multiple Intelligences; Kecerdasan Majemuk Teori dalam Praktek. (Alih bahasa Alexander Sindoro). Batam Center: Interaksara.

Gladding, S.T. (1995). Group Work: A Counseling Specialty. Englewood Cliffs, New Jersey: Merrill an imprint of Prentice Hall.

Goleman, D. (1995). Emotional Intelligence. New York: Bantam Books.

Goleman, D. (2007). Social Intelligence: The New Science of Human Relationships. London: The Random House Group Limited.

Goleman, D. (2009). Ecological Intelligence. New York: Broadway Books.

Hay, D.F., Castle, J., \& Jewett, J. (1994). Development Through Life; A Handbook for Clinician. Blackwell Science.

Imaddudin, A. (2011). Bimbingan dan Konseling Aktualisasi Diri Untuk Meningkatkan Kecerdasan Spiritual Siswa Sekolah Dasar.(Tesis). Bandung: Program Studi Bimbingan dan Konseling, Sekolah Pascasarjana: UPI.

Kumpfer, K.L. (2010). Best Practices Personal \& Social Skills. Dalam
Wisconsin Clearinghouse for Prevention Resources. [Tersedia]Personal\%20\&\%20Social\% 20Skills(3/23/2010).

Pardiansyah, A. (2003). You are A Leader. Menjadi Pemimpin dengan memanfaatkan Potensi Terbesar yang Anda Miliki: Kekuatan Memilih. Jakarta: PT Elex Media Komputindo.

Picklesimer, B.K., \& Miller, T.K. (1998). Lifeskills development inventory-college form: An assessment measure, Journal of College Student Development. FindArticles.com. 30 Oct. 2007.

Sinamo, J. (2000). Strategi Adaptif Abad ke-21: Berselancar di Atas Gelombang Krisis. Jakarta: Gramedia.

Stoltz, P.G. (1997). Adversity Quotient; Turning Obstacles into Opportunities. New York: John Wiley \& Sons, Inc.

Stone, G.L. (1995). Attachment Theory. The Counseling Psychologist, 23, 3. Division of Counseling Psychology of the American Psychological Association: Sage Periodicals Press.

Sukartini, S. P. (2003). Model Konseling Keterampilan Hidup Untuk Mengembangkan Dimensi Kendali Pribadi yang Tegar. (Disertasi). Bandung: Universitas Pendidikan Indonesia.

Supriatna, M. (2016a). Efektivitas Model Konseling Aktualisasi Diri untuk Mengembangkan Kecakapan Prubadi. (Makalah) Dalam Proceeding Seminar Nasional 2016; Konseling dan Psikoterapi dalam Menghadapi Dampak Pasar Bebas Dunia. Lombok NTBIndonesia: STKIP Hamzanwadi dan Asosiasi Bimbingan dan Konseling Indonesia.

Supriatna, M. (2016b). Model Konseling Aktualisasi Diri untuk Mengembangkan Kecakapan Prubadi. (Makalah) Dalam Prosiding Konvensi Nasional XIX ABKIN; Penguatan Teori dan Praktik Konseling Dalam membangun SDM yang Berkarakter dan Berbudaya Bangsa. Banjarmasin: Universitas Lambung Mangkurat.

Wu, Wu-Tien. (1998). Toward a Successful Career through Personal Intelligence: A Chinese Cultural Point of View, (Paper). New Delhi: The $5^{\text {th }}$ Asia-Pacific Conference on Giftedness. 
Wu, Wu-Tien. (2001). Conception and Appraisal of Personal Intelligence, (Paper). Barcelona: The $14^{\text {th }}$ World Conference of the World Council for Gifted and Talented Children.

$\mathrm{Wu}$, Wu-Tien. (2003). Multiple Intelligence, Educational Reform, and A Successful Career, (Paper). Chicago: The AERA Annual Meeting.

Zohar, D. \& Marshall, I. (2000). SQ: Spiritual Intelligence; The Ultimate Intelligence. London: Bloomsbury. 